\title{
Elaboration and characterization of new phosphate glasses based on natural phosphate and red clay: influence of the chemical composition on the chemical durability
}

\author{
Oumaima Jamal Eddine ${ }^{1, *}$, Mehdi El Bouchti ${ }^{2}$, Omar Cherkaoui ${ }^{2}$, Hassan Hannache ${ }^{1,3}$ and \\ Said Gmouh ${ }^{1}$ \\ ${ }^{1}$ University Hassan II of Casablanca, Faculty of Sciences Ben M'Sik, Chemistry Department, LIMAT, \\ Avenue Driss El Harti, Casablanca, Morocco \\ ${ }^{2}$ Higher School of Textile and Clothing Industries, Laboratory REMTEX, km 8, Route d'El Jadida, \\ BP 7731 - Oulfa, Casablanca, Morocco \\ ${ }^{3}$ University Mohammed VI Polytechnic, Materials Science and Nanoengineering Department, Lot 660, Hay \\ Moulay Rachid, Benguerir, Morocco
}

\begin{abstract}
New phosphate glass formulations based on Moroccan natural phosphate minerals alone or with Moroccan red clay additive (containing the $\mathrm{P}_{2} \mathrm{O}_{5}-\mathrm{SiO}_{2}-\mathrm{CaO}-\mathrm{Al}_{2} \mathrm{O}_{3}-\mathrm{MgO}-\mathrm{Fe}_{2} \mathrm{O}_{3}-\mathrm{K}_{2} \mathrm{O}-\mathrm{Na}_{2} \mathrm{O}-\mathrm{TiO}_{2}$ complex) have been successfully prepared by the quenching method. The chemical composition of each of the elaborated phosphate glasses was determined by X-ray fluorescence analysis (XRF). These investigated phosphate glasses have an excellent homogeneity as was verified by SEM. Their amorphous behavior was confirmed by XRD and DSC. The increase in density and glass transition temperature due to the addition of clay is believed to be related to the crosslinking of the phosphate chains. Structural investigation of these phosphate glasses was carried out using FTIR and Raman spectroscopies. The results obtained show that the composition of these glasses contains a mixture of ultraphosphate and polyphosphate structural units. The concentrations of this mixture depending on the initial composition of the glass components. A correlation between the chemical composition and the chemical durability of the investigated glasses was studied. The results showed that the dissolution rate of the glasses decreases by increasing the clay composition up to a point. This can be explained by assuming the formation of oxygen bridges and strong bonds within the various glasses.
\end{abstract}

Keywords: Natural phosphate; Red clay; Phosphate glasses; Chemical composition; Chemical durability.

\section{Introduction}

Phosphate glasses (PGs) currently compete with silica glasses because are characterized by their high UV transparency, low IR transparency, and high thermal expansion, as well as their electrical and optical characteristics. Owing to these properties, phosphate glasses offer a unique range of applications, such as glass-polymer composite materials ${ }^{1}$, slow-release fertilization ${ }^{2}$, nuclear waste immobilization matrices ${ }^{3}$, conductive materials ${ }^{4}$ amorphous semiconductors ${ }^{5}$, optical waveguides ${ }^{6}$, and solid-state laser ${ }^{7}$.

Phosphate glasses are mainly composed of tetrahedral units $\mathrm{PO}_{4}{ }^{3-}$. The double bond $(\mathrm{P}=\mathrm{O})$ in these tetrahedra causes polarization of the other $\mathrm{P}-\mathrm{O}$ bonds and increases the ionicity of the P-O-M bonds (with $\mathrm{M}=\mathrm{Fe}, \mathrm{Zn}, \mathrm{Al}, \mathrm{B}, \mathrm{Pb}, \mathrm{Si}, \mathrm{N}$...). This limits the rate of glass crosslinking by minimizing

*Corresponding authors: Said Gmouh

E mail: s.gmouh1@gmail.com

DOI: http://dx.doi.org/10.13171/mjc93191012614sg the network condensation and making the composition easily hydrolysable ${ }^{8,9,10}$. It is this major disadvantage of phosphate glasses, their poor chemical durability against corrosion agents, that has dramatically limited their development $8,11,12$. In order to solve this problem, it has been shown by others that the introduction of multivalent cations allows the formation of more covalent bonds and the reinforcement of glassy networks against hydrolysable attack through the formation of ionic

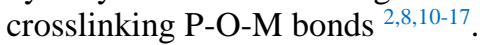

In recent years, complex phosphate glasses have attracted increasing interest. For example, Brauer and al. ${ }^{14}$ studied a quaternary phosphate glass system $\mathrm{P}_{2} \mathrm{O}_{5}-\mathrm{CaO}-\mathrm{Na}_{2} \mathrm{O}-\mathrm{MgO}-\mathrm{TiO}_{2}$ which reported that the addition of titanium oxide produced glasses that were more stable to dissolution. Khan et al. ${ }^{13}$ have reported a quaternary phosphate glasses in the glassy system $\mathrm{P}_{2} \mathrm{O}_{5}-\mathrm{CaO}-\mathrm{Na}_{2} \mathrm{O}-\mathrm{MgO}-\mathrm{Fe}_{2} \mathrm{O}_{3}$ and

Received July 5, 2019

Accepted October 1, 2019

Published October 12, 2019 
found that the addition of $\mathrm{Fe}_{2} \mathrm{O}_{3}$ makes the phosphate glasses of this system more durable which can be explained by the formation of Fe-O-P bonds which replaces that of P-O-P. Waclawska et al. ${ }^{2}$ studied the influence of the addition of $\mathrm{ZnO}$ on the structure of multicomponent glasses system $\mathrm{SiO}_{2}-\mathrm{P}_{2} \mathrm{O}_{5}-\mathrm{K}_{2} \mathrm{O}$ $\mathrm{CaO}-\mathrm{MgO}-\mathrm{ZnO}$ acting as a slow-release fertilizer, and found that the introduction of up to $15 \mathrm{~mol} \%$ of $\mathrm{ZnO}$ substituting $\mathrm{CaO}$ and $\mathrm{MgO}$ into the structure of the studied glasses causes the depolymerisation of the silicate phosphate network. In addition, other works show that the rate of degradation decreases with increasing content of some elements such as $\mathrm{Al}$, $\mathrm{Mg}, \mathrm{N}, \mathrm{B}$, and $\mathrm{Zr}^{3,9,12,17,18}$.

In this context, the objective of this work was on the one hand to develop new formulations of phosphate glasses based on inexpensive raw minerals, from which we used Moroccan natural phosphate and Moroccan red clay. On the other hand, we wished to increase the chemical durability of phosphate glasses, which strongly depends on their compositions, structures, etching solution, temperature and $\mathrm{pH}$ of the solution 13,14,17. The phosphate glasses synthesized contain all the macroelements ( $\mathrm{P}, \mathrm{Ca}, \mathrm{Mg}$, and $\mathrm{K}$ ) and microelements ( $\mathrm{Si}, \mathrm{Al}, \mathrm{Fe}, \mathrm{Na}$, and $\mathrm{Ti}$ ) would then be used to develop phosphate glass fibers acting as a slow-release fertilizer, with high chemical durability and high mechanical resistance.

\section{Experimental}

\subsection{Raw materials}

Natural raw materials used in this study were: Moroccan natural phosphate (NP) extracted from one of the mines of the Ouled Abdoun basins in Khouribga region, and Moroccan red clay (RC): extracted from Berrechid region, which belongs to the western Moroccan Meseta (red triassic clays). The mineralogy of the raw materials was determined by XRF, XRD, and FTIR.

\subsection{Glass preparation}

A series of multicomponent phosphate glasses (PGs) systems were prepared by mixing the natural phosphate (NP) and the red clay (RC) in crude forms separately (RC-x: $x=0,2,5,10$, or 15 (in weight percentage of $\mathrm{RC}(\mathrm{wt} \%)$ ). A reference glass without the addition of clay was also prepared (NP-glass or RC-0). These five glasses were prepared using the melt-quenching method. The mixture corresponding to the desired compositions was firstly heated at $600^{\circ} \mathrm{C}$ for $2 \mathrm{~h}$. Then the temperature was progressively raised from $600^{\circ} \mathrm{C}$ to $1100^{\circ} \mathrm{C}$, depending on the glass composition and held constant for $1 \mathrm{~h}$ in an electrically heated furnace. The molten liquid was quenched to room temperature under the air atmosphere in order to produce a vitreous network. Table 1 shows the photographs of the elaborate phosphate glasses.

Table 1. Photographs of the elaborate phosphate glasses.

\begin{tabular}{|c|c|c|c|c|c|}
\hline Glass code & NP-glass & $\mathrm{RC}-2$ & RC-5 & RC-10 & RC-15 \\
\hline Glass sample & & & & & \\
\hline
\end{tabular}

\subsection{X-Ray Fluorescence analysis}

Chemical analysis of the raw materials and the annealed phosphate glasses (PGs) samples was carried out by X-Ray Fluorescence spectrometer (XRF).

\subsection{SEM analysis}

The SEM micrographs of the PGs were recorded using a ZEISS Supra 55VP scanning electron microscope operating under high vacuum at $3 \mathrm{kV}$ and using a secondary electron detector (EverhartThornley detector). A sample of phosphate glass was dried and then deposited on the surface of an adhesive carbon film, and a $20 \mathrm{~nm}$ gold coating was sputtered on the surface to make them conductive.

\subsection{X-ray diffraction analysis}

The amorphous behaviour of the elaborated PGs was confirmed by the XRD analysis using a Siemens
D501 diffractometer, equipped with a copper anticathode tube and a secondary monochromatic $\left(\mathrm{Cu}-\mathrm{K} \alpha\right.$ radiation $\left.\lambda_{\mathrm{Cu}}=1.5406 \AA\right)$.

\subsection{Thermal analysis}

The glass transition temperatures $(\mathrm{Tg})$ were determined by DSC on 20 to $30 \mathrm{mg}$ of beautiful powder samples of phosphate glass using the TGA/DSC 1 (Mettler Toledo) with $10^{\circ} \mathrm{C} \mathrm{min}^{-1}$ constant heating rate (accuracy $\pm 2{ }^{\circ} \mathrm{C}$ ) under argon flow. The apparatus cools under nitrogen.

\subsection{Density and molar volume measurement}

The densities of the PGs were measured at room temperature via Archimedes method according to BS $10119^{19}$, in which ethanol (from Sigma-Aldrich) was used as the working fluid using Eq. (1). The error of the density measurements was within $\pm 0.03 \mathrm{~g} . \mathrm{cm}^{-3}$. The molar volume was calculated 
from the density of glass and the molar weight $\left(\mathrm{V}=\mathrm{M} / \rho_{\mathrm{g}}\right)$.

$$
\rho_{\mathrm{g}}=\left(\mathbf{m}_{\mathrm{a}} /\left(\mathbf{m}_{\mathrm{a}}-\mathbf{m}_{\mathrm{w}}\right)\right) \times \boldsymbol{\rho}_{\mathrm{e}}
$$

Where $\boldsymbol{\rho}_{\mathrm{g}}$ is the density of glass sample, $\boldsymbol{\rho}_{\mathbf{e}}$ is the density of ethanol, $\mathbf{m}_{\mathbf{a}}$ is the mass of dry glass weighed in air, and $\mathbf{m}_{\mathbf{w}}$ is the mass of glass immersed in ethanol.

\subsection{FTIR spectroscopy}

The FTIR absorption spectra of PGs were made using a Thermo Electron (Nicolet 5700-FTIR model) spectrometer equipped with diamond microATR accessory and recorded in the range of $400-4000 \mathrm{~cm}^{-1}$.

\subsection{Raman spectroscopy}

The Raman spectra of PGs were recorded at room temperature in the $200-3300 \mathrm{~cm}^{-1}$ range using a Thermo Fisher XRD 2 RAMAN spectrometer equipped with an internal $\mathrm{He}-\mathrm{Ne}$ laser source ( $8 \mathrm{~mW}$ ) under an excitation $\lambda=633 \mathrm{~nm}$ and a CCD detector (Thermo, USA).

\subsection{Chemical durability}

Each solid glass sample was first annealed at (Tg-20) ${ }^{\circ} \mathrm{C}$ for $8 \mathrm{~h}$ to eliminate residual stresses, then cut and dry polished using standard $\mathrm{SiC}$ abrasive paper to a circular shape to avoid preferential corrosion. Then each piece of glass was washed with acetone and dried at $102^{\circ} \mathrm{C}$ for 30 minutes. The sample thus prepared was weighed and then placed in a flask containing the already prepared alternative solution $(\mathrm{pH}=5 ; 7 ;$ and 8$)$, then heated to a temperature of $30 \pm 3^{\circ} \mathrm{C}$ under agitation for 6 days. The $\mathrm{pH}$ of each alternative solution was adjusted by a buffer solution whose composition is presented in Table 2. After filtration, each glass sample was rinsed with acetone and dried at $102^{\circ} \mathrm{C}$ for 30 minutes. The final mass and dimensions of the glass piece were then measured.

Table 2. Composition of the buffer solution ${ }^{20}$.

\begin{tabular}{|c|c|}
\hline $\mathbf{p H} \pm \mathbf{0 . 1}$ & Composition \\
\hline $\mathbf{5}$ & Acetic acid + sodium acetate \\
\hline $\mathbf{7}$ & Acetic acid + concentrated ammonia \\
\hline $\mathbf{8}$ & Acetic acid + concentrated ammonia \\
\hline
\end{tabular}

The chemical durability of investigated phosphate glasses was evaluated in terms of dissolution rate $\left(D_{R}\right)$ as weight loss per unit surface area per unit time $\left(\mathrm{g} \cdot \mathrm{cm}^{-2} \cdot \mathrm{min}^{-1}\right)$ according to Eq. (2):

$D_{R}=\Delta \mathbf{m} /(\mathbf{S} \times \mathbf{t})$

Where $\Delta \mathbf{m}$ is the mass loss ( $\mathrm{g}), \mathbf{S}$ is the surface area $\left(\mathrm{cm}^{2}\right)$ of the glass, and $\mathbf{t}$ is the time (min) of immersion of the glass in the solution. The estimated error was calculated to be $\pm 2 \mathrm{~g} \cdot \mathrm{cm}^{-2} \cdot \mathrm{min}^{-1}$.

\section{Results and Discussion}

\subsection{Raw material characterization}

The combination of the results of different analysis methods: XRF, XRD and FTIR allowed us to determine the chemical and mineralogical compositions of the minerals used in this study. Table 3 presents the standardized results of the XRF analysis of the raw materials (\%wt). The results of the chemical analysis show that the NP contains significant percentages of $\mathrm{CaO}, \mathrm{P}_{2} \mathrm{O}_{5}$, whereas the $\mathrm{RC}$ analysis showed a dominance of silica and relatively high concentrations of $\mathrm{Al}_{2} \mathrm{O}_{3}$, as well as a higher percentage of $\mathrm{Fe}_{2} \mathrm{O}_{3}, \mathrm{~K}_{2} \mathrm{O}$, and $\mathrm{MgO}$.

Table 3. Chemical analysis (wt\%) of the raw materials.

\begin{tabular}{|c|c|c|c|c|c|c|c|c|c|c|c|c|}
\hline & Oxides & $\mathbf{P}_{2} \mathbf{O}_{5}$ & $\mathrm{CaO}$ & $\mathrm{SiO}_{2}$ & $\mathrm{Al}_{2} \mathrm{O}_{3}$ & $\mathrm{Fe}_{2} \mathrm{O}_{3}$ & MgO & $\mathrm{K}_{2} \mathrm{O}$ & $\mathrm{Na}_{2} \mathrm{O}$ & $\mathrm{TiO}_{2}$ & MnO & $\mathrm{ZnO}$ \\
\hline \multirow{2}{*}{$\begin{array}{c}\text { Raw } \\
\text { material, } \\
(\text { wt \% })\end{array}$} & NP & 34.97 & 58.88 & 3.67 & 0.44 & 0.26 & 0.70 & 0.08 & 0.92 & 0.03 & 0.01 & 0.03 \\
\hline & $\mathrm{RC}$ & 0.16 & 3.74 & 60.50 & 17.71 & 7.36 & 3.99 & 5.10 & 0.55 & 0.76 & 0.11 & -- \\
\hline
\end{tabular}

The X-ray pattern obtained for the NP (Fig. 1a) shows the presence of the following phases: fluorapatite $\mathrm{Ca}_{5}\left(\mathrm{PO}_{4}\right)_{3} \mathrm{~F}$ as the primary phase, calcium carbonates $\mathrm{CaCO}_{3}$ (calcite) and quartz $\mathrm{SiO}_{2}$. The latter two are exogangue in nature, and the interference of these phases with fluorapatite is due to their endogangue nature. Jointly, they constitute the francolite. In addition, it should be noted that there are small peaks of minority phases and that there may also be amorphous phases.

The bands observed in the infrared spectrum of the NP (Fig. 1b) can be divided into different domains: those between $950 \mathrm{~cm}^{-1}$ and $1110 \mathrm{~cm}^{-1}$ are attributed to the symmetrical and asymmetrical elongation vibrations of the $\mathrm{PO}_{4}$ groups; those between $460 \mathrm{~cm}^{-1}$ and $602 \mathrm{~cm}^{-1}$ are attributed to the symmetrical deformation vibrations of the $\mathrm{PO}_{4}$ groups; valence vibrations of calcite $\mathrm{CaCO}_{3}$ groups are observed at $1426 \mathrm{~cm}^{-1}$ and $1454 \mathrm{~cm}^{-1}$; the adsorption bands centred at $1812 \mathrm{~cm}^{-1}, 1637 \mathrm{~cm}^{-1}, 795 \mathrm{~cm}^{-1}$, and 648 $\mathrm{cm}^{-1}$ are attributed to traces of the carbonyl compounds; in addition, the stretching vibration bands between $780 \mathrm{~cm}^{-1}$ and $800 \mathrm{~cm}^{-1}$ are assigned to the vibration of the silicate groups. The infrared spectrum of the Khouribga NP shows no characteristic absorption band of $\mathrm{OH}^{-}$hydroxyl ions at $3560 \mathrm{~cm}^{-1}$ and $630 \mathrm{~cm}^{-1}$, confirming that this phosphate is a carbonate fluorapatite (francolite) 

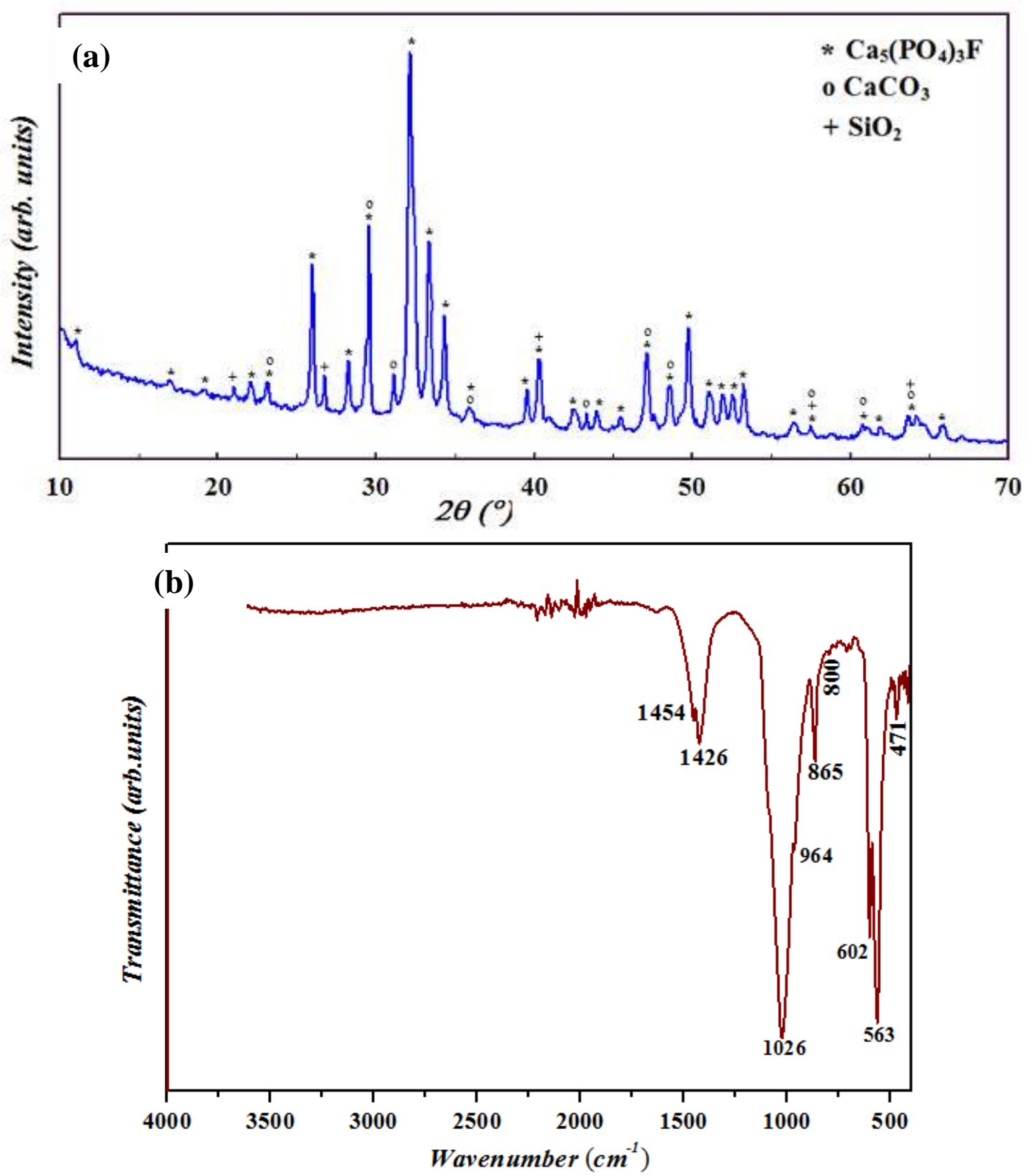

Figure 1. (a) X-ray diffractogram and (b) Infrared spectrum of natural phosphate from Khouribga.

The X-ray pattern of the red clay (Fig. 2a) shows a predominance of quartz $\left(\mathrm{SiO}_{2}\right)$ and kaolinite $\left(\mathrm{Al}_{2} \mathrm{Si}_{2} \mathrm{O}_{5}(\mathrm{OH})_{4}\right)$, as well as illite $\left(\mathrm{K}_{0,75} \mathrm{Na}_{0,01} \mathrm{Mg}_{0,15} \mathrm{Fe}_{0,04} \mathrm{Al}_{2,59} \mathrm{Si}_{3,27} \mathrm{O}_{10}(\mathrm{OH})_{2}\right) \quad$ and muscovite $\mathrm{KAl}_{2}\left(\mathrm{Al} \mathrm{Si}_{3} \mathrm{O}_{10}\right)(\mathrm{OH})_{2}$ which have very similar peaks. This does not allow easy distinction between the two phases ${ }^{21}$. The results showed also the presence of chlorite $(\mathrm{Mg}, \mathrm{Fe}$, $\mathrm{Al})_{6}\left[\mathrm{AlSi}_{3} \mathrm{O}_{10}\right](\mathrm{OH})_{8}$ and hematite $\mathrm{Fe}_{2} \mathrm{O}_{3}$, as well as calcite $\mathrm{CaCO}_{3}$ and dolomite $\mathrm{MgCa}\left(\mathrm{CO}_{3}\right)_{2}$ as an impurities source. These results show that this natural clay is rich in clay minerals and poor in carbonates. Nonetheless, it was found within perfect agreement with the results of XRF, which shows high proportions of $\mathrm{SiO}_{2}$ and $\mathrm{Al}_{2} \mathrm{O}_{3}$ and an expected presence of iron, potassium, magnesium, and calcium content. In addition, the $\mathrm{SiO}_{2} / \mathrm{Al}_{2} \mathrm{O}_{3}=3.4$ ratio is a characteristic index of free quartz ${ }^{22}$.

The infrared spectrum of the $\mathrm{RC}$ obtained is illustrated in Fig. 2b. The frequencies and their allocations are given in Table 4. Infrared spectroscopy was used to complete the analysis of the clay sample. The results are in agreement with those found from XRD. They confirm the presence of quartz and kaolinite as major phases and carbonate as a minor phase in the red clay studied. 

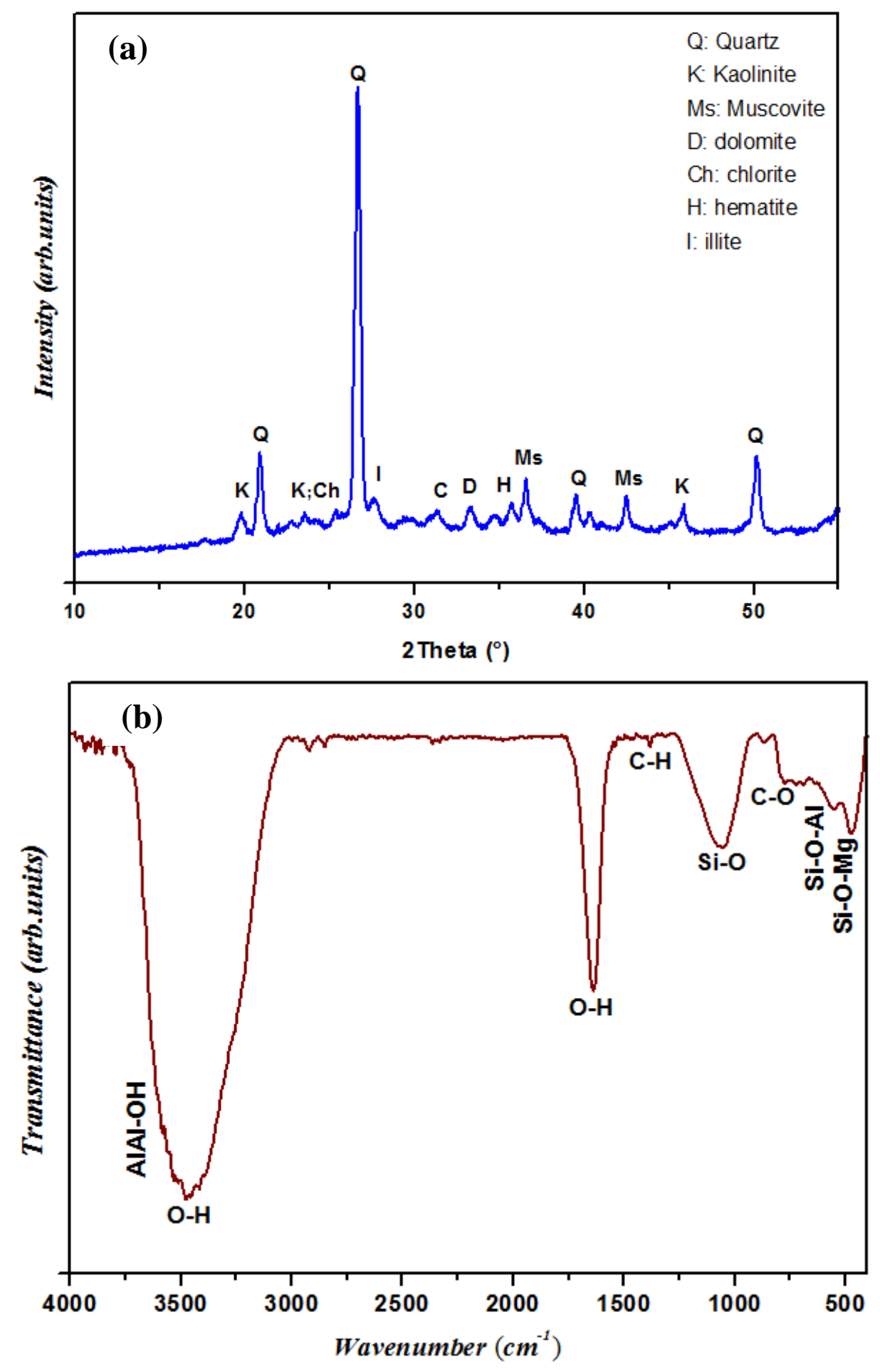

Figure 2. (a) X-ray diffractogram and (b) Infrared spectrum of the red clay from Berrechid. 
Table 4. Frequencies $\left(\mathrm{cm}^{-1}\right)$ and allocations of infrared bands characteristic of the red clay from the Berrechid region.

\begin{tabular}{|c|c|}
\hline $\begin{array}{l}\text { Wavenumber } \\
\quad\left(\mathbf{c m}^{-1}\right)\end{array}$ & Attributions \\
\hline 3585 & $\begin{array}{l}\text { Between } 3700 \mathrm{~cm}^{-1} \text { and } 3620 \mathrm{~cm}^{-1} \text { : vibrations of the structural hydroxyl groups AlAl-OH } \\
\text { characteristic of kaolinite }\end{array}$ \\
\hline 3477 & $\begin{array}{l}\text { Wideband around } 3477 \mathrm{~cm}^{-1} \text { indicating the presence of a hydroxyl group (O-H stretching } \\
\text { vibrations) }\end{array}$ \\
\hline 1796 & Between $1770 \mathrm{~cm}^{-1}$ and $1800 \mathrm{~cm}^{-1}$ : Elongation vibration $\mathrm{C}=\mathrm{O}$ \\
\hline 1634 & Deformation vibration of free $\mathrm{H}_{2} \mathrm{O}$ \\
\hline 1383 & $\begin{array}{l}\text { Between } 1500 \mathrm{~cm}^{-1} \text { and } 1400 \mathrm{~cm}^{-1} \text { : Symmetrical deformation vibration of the } \mathrm{CH}_{3} \text { groups } \\
\text { around } 1383 \mathrm{~cm}^{-1}\end{array}$ \\
\hline 1058 & Elongation vibration of the $\mathrm{Si}-\mathrm{O}$ bond of kaolinite or quartz \\
\hline 870 and 722 & Characteristic bands of $\mathrm{C}-\mathrm{O}$ carbonates \\
\hline 778 & Quartz \\
\hline 628 & Vibrations characteristic of $\mathrm{Si}-\mathrm{O}$ or $\mathrm{Si}-\mathrm{OH}$ (deformation) and/or $\mathrm{Al}-\mathrm{O}$ (elongation) \\
\hline 556 & Deformation vibration of the $\mathrm{Si}-\mathrm{O}-\mathrm{Al}$ bond \\
\hline 474 & $\begin{array}{l}\text { Between } 550 \mathrm{~cm}^{-1} \text { and } 400 \mathrm{~cm}^{-1} \text { : deformation vibration of the Si-O-Mg bond that partially } \\
\text { overlaps with the Si-O bending absorption, resulting in a single strong band located near } 474\end{array}$ \\
\hline
\end{tabular}

\subsection{Glass Characterization}

\subsubsection{X-ray fluorescence analysis}

The structure of the phosphate glasses is highly dependent on the oxygen/phosphate $(\mathrm{O} / \mathrm{P})$ ratio, which varies according to the oxide content in these glasses, as demonstrated by several previous studies ${ }^{2,9,23-26}$. The calculated values of $\mathrm{O} / \mathrm{P}$ are summarized in Table 5. For the reference glass (NP-glass) containing $50 \mathrm{~mol} \%$ of $\mathrm{P}_{2} \mathrm{O}_{5}$, the ratio was $\mathrm{O} / \mathrm{P}=2.73$, and when $2 \%$ and $5 \%$ by weight of the red clay were added ( $\mathrm{RC}-2$ and $\mathrm{RC}-5)$, the ratio increased to $\mathrm{O} / \mathrm{P}=2.91$ and 2.97 respectively, which characterizes the ultraphosphate glasses $(5 / 2<\mathrm{O} / \mathrm{P}<3)$ of a long phosphate chain with 3 oxygen bridges $\left(\mathrm{Q}^{3}\right)$. When $10 \%$ and $15 \%$ by weight of clay were added, the ratio increased to $\mathrm{O} / \mathrm{P}=3.08$ and 3.13 respectively for RC-10 and RC-15 phosphate glasses. This is the case for polyphosphate glasses, which are made up of infinite chains of $\mathrm{PO}_{4}$ tetrahedra $\left(\mathrm{Q}^{2}\right.$ chains ending in $\mathrm{Q}^{1}$ units). Similar results were obtained by Ahmed et al. ${ }^{11}$ who found that $\mathrm{Q}^{3}$ species were present in glasses containing more than $50 \mathrm{~mol} \%$ of $\mathrm{P}_{2} \mathrm{O}_{5}$ and $\mathrm{Q}^{1}$ species were present in glasses containing less than 50 mol\% $\mathrm{P}_{2} \mathrm{O}_{5}$. 
Table 5. Chemical compositions of the PGs in weight percent (wt\%) and molar percent (mol\%).

\begin{tabular}{|c|c|c|c|c|c|c|c|c|c|c|c|c|c|c|c|c|c|c|c|c|}
\hline \multirow{3}{*}{$\begin{array}{l}\text { Glass } \\
\text { code }\end{array}$} & \multicolumn{19}{|c|}{ Chemical composition } & \multirow[t]{3}{*}{ O/P } \\
\hline & \multicolumn{2}{|c|}{$\mathrm{P}_{2} \mathrm{O}_{5}$} & \multicolumn{2}{|c|}{$\mathrm{CaO}$} & \multicolumn{2}{|c|}{$\mathrm{SiO}_{2}$} & \multicolumn{2}{|c|}{$\mathrm{Al}_{2} \mathrm{O}_{3}$} & \multicolumn{2}{|c|}{$\mathrm{Fe}_{2} \mathrm{O}_{3}$} & \multicolumn{2}{|c|}{ MgO } & \multicolumn{2}{|c|}{$\mathrm{K}_{2} \mathrm{O}$} & \multicolumn{2}{|c|}{$\mathrm{Na}_{2} \mathrm{O}$} & \multicolumn{2}{|c|}{$\mathrm{TiO}_{2}$} & \multirow{2}{*}{$\begin{array}{l}\text { ZnO } \\
\text { wt\% }\end{array}$} & \\
\hline & wt\% & mole & wt\% & mol\% & wt\% & mol\% & wt\% & $\mathrm{mol} \%$ & wt\% & mol\% & wt\% & mol\% & wt\% & mol\% & wt\% & mol\% & wt\% & mol\% & & \\
\hline NP-glass & 70.81 & 50 & 25.06 & 45 & 2.46 & 4.09 & 0.61 & 0.60 & 0.14 & 0.09 & 0.38 & 0.94 & 0.08 & 0.09 & 0.41 & 0.66 & 0.03 & 0.04 & 0.02 & 2.73 \\
\hline$R C-2$ & 66.60 & 47 & 16.11 & 29 & 7.25 & 12.07 & 4.74 & 4.65 & 2.32 & 1.45 & 1.20 & 2.98 & 1.41 & 1.50 & 0.24 & 0.39 & 0.13 & 0.16 & 0.00 & 2.91 \\
\hline$R C-5$ & 65.05 & 46 & 14.10 & 25 & 9.34 & 15.55 & 5.25 & 5.15 & 2.94 & 1.84 & 1.35 & 3.35 & 1.59 & 1.69 & 0.23 & 0.37 & 0.15 & 0.19 & 0.00 & 2.97 \\
\hline$R C-10$ & 60.00 & 42 & 13.87 & 25 & 13.92 & 23.17 & 4.26 & 4.18 & 3.66 & 2.29 & 1.49 & 3.70 & 2.33 & 2.47 & 0.30 & 0.48 & 0.17 & 0.21 & 0.00 & 3.08 \\
\hline$R C-15$ & 58.38 & 41 & 13.86 & 25 & 14.11 & 23.49 & 3.94 & 3.86 & 4.68 & 2.93 & 1.46 & 3.62 & 3.02 & 3.21 & 0.38 & 0.61 & 0.17 & 0.27 & 0.00 & 3.13 \\
\hline
\end{tabular}




\subsubsection{SEM analysis}

All samples of the prepared phosphate glasses appear transparent and homogeneous under daylight (Table 1). The following figure (Fig. 3) shows two examples of SEM micrographs of NP-glass

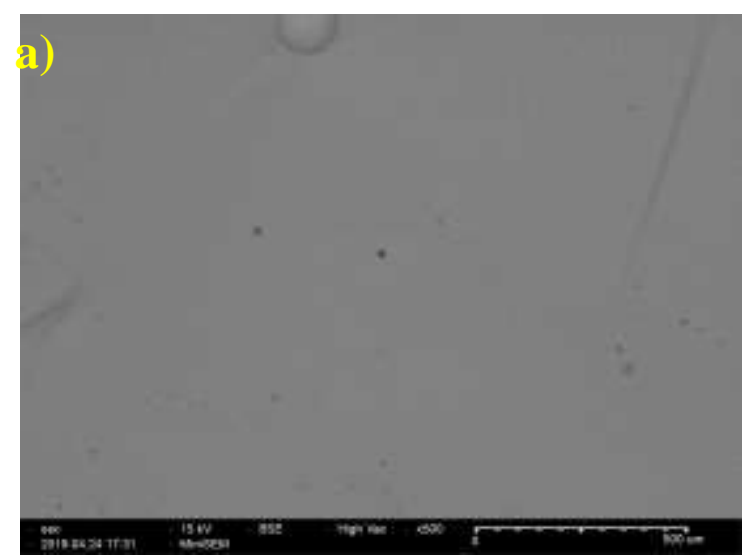

phosphate glass (Fig. 3a) and RC-15 phosphate glass fractions (Fig. 3b). As expected, the surface is smooth that there are no cracks were visible on the surface at 500 times magnification.

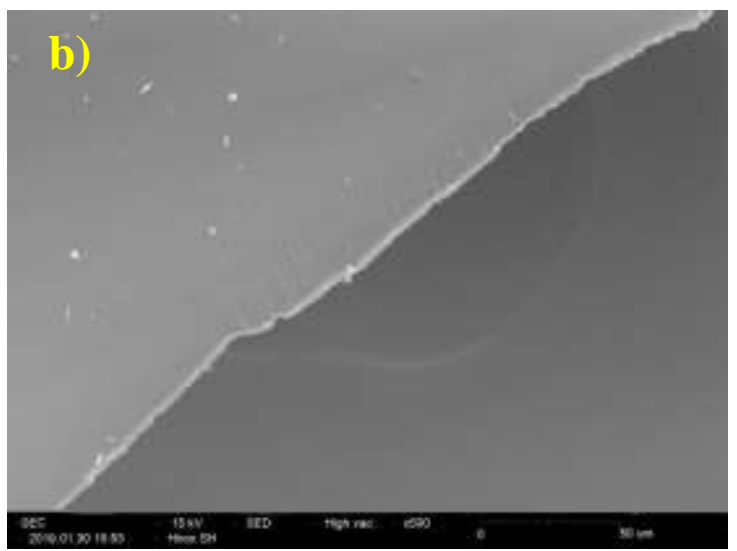

Figure 3. SEM micrographs (x 500) of two PGs: (a) reference glass (NP-glass), and (b) glass contains $15 \%$ of red clay (RC-15).

\subsubsection{X-ray diffraction analysis}

XRD patterns of all compositions of elaborated PGs are shown in Fig. 4. All spectra of glasses showed a lack of sharp peaks between $10^{\circ}$ and $70^{\circ}(2 \theta)$, which characterizes long-range disorder in the vitreous network.

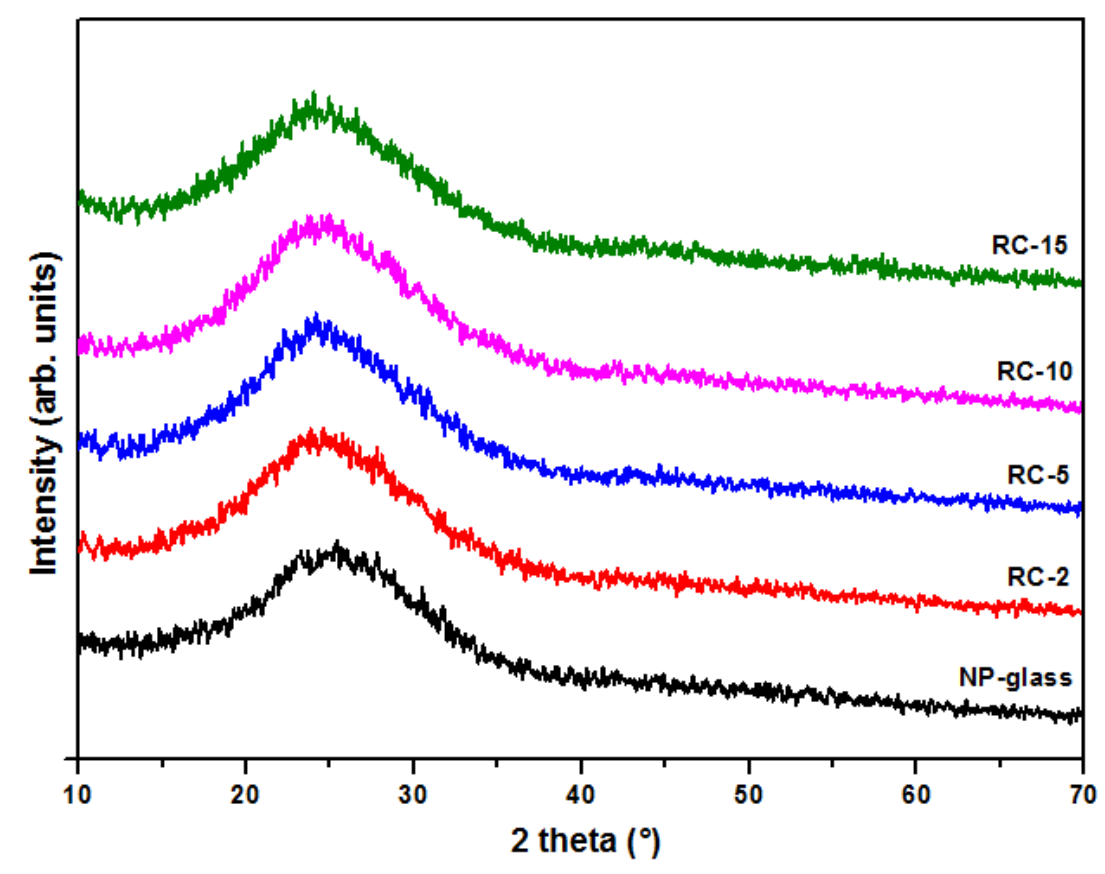

Figure 4. XRD spectra of elaborated phosphate glasses.

3.2.4. Density, molar volume, and thermal analysis

The density of glass is an important factor in determining the degree of change of the structure within the glass as the composition of the glass changes due to the addition of modifying oxides. The values of the calculated density and molar volume measurements of phosphate glass samples studied here are given in Table 6, while the variation of these two factors concerning the amount of clay added is presented in Fig. 5.

The results showed that the density of glasses gradually increases with the clay content in the glass, which increases from $\rho_{\mathrm{g}}=2.6359 \mathrm{~g} . \mathrm{cm}^{-3}$ for reference glass to $\rho_{\mathrm{g}}=2.9542 \mathrm{~g} . \mathrm{cm}^{-3}$ for RC-15. Conversely, the molar volume decreases monotonously with the introduction of clay. It varies from $\mathrm{Vm}=44.54$ for NP-glass to $\mathrm{Vm}=38.73$ for $\mathrm{RC}-15$. 


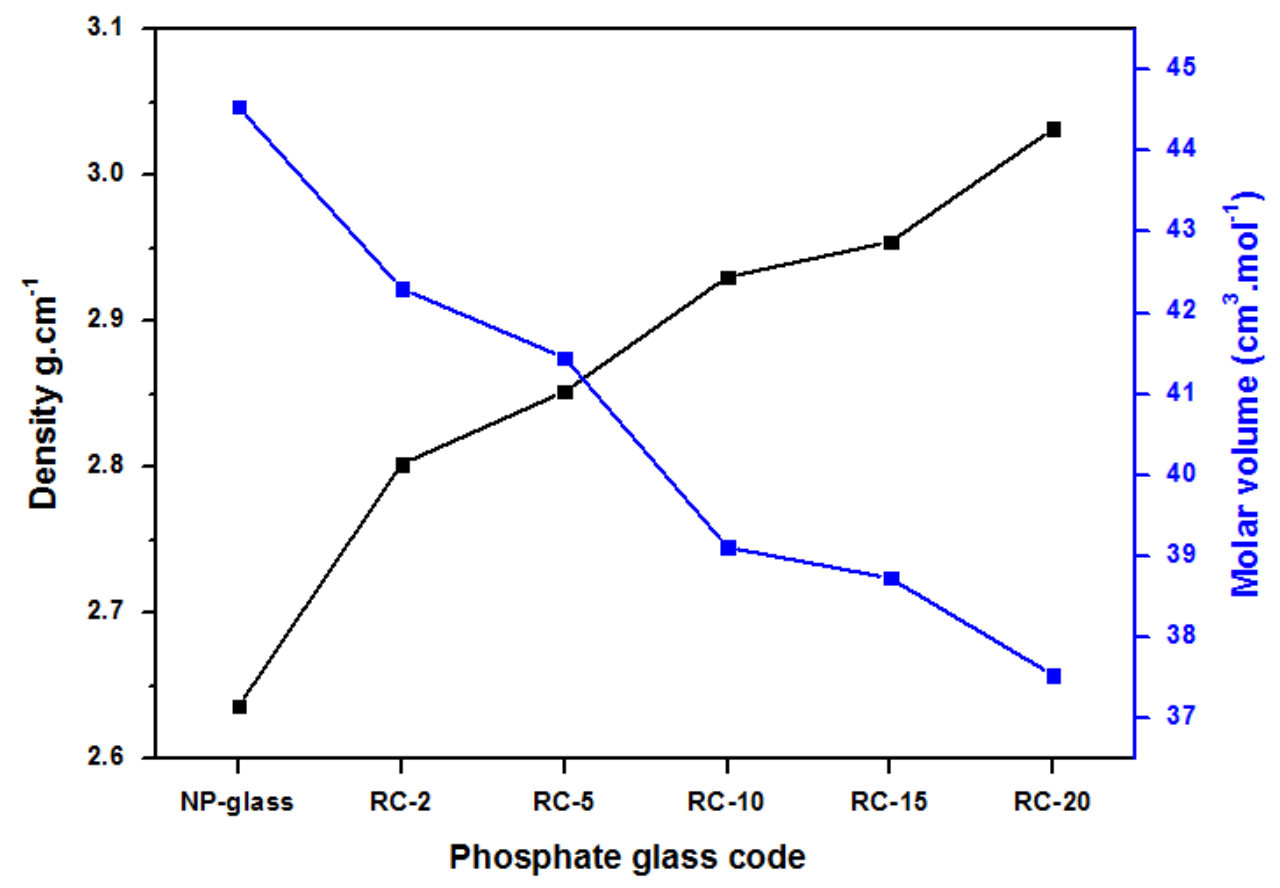

Figure 5. Composition dependence of density and molar volume of PGs containing red clay.

Fig. 6 shows DSC curves of NP-glass, RC-5, and RC-15 phosphate glasses. The values of the glass transition temperature $(\mathrm{Tg})$ are given in Table 6 . The results show that the $\mathrm{Tg}$ values increase with the clay content in the phosphate glass. It varies from $392^{\circ} \mathrm{C}$ for NP-glass to $491^{\circ} \mathrm{C}$ for RC-15. Thus, this increase in $\mathrm{Tg}$ could be correlated to several factors such as the modification of the bond strength and the crosslinking of the glassy network with the increase in atomic packing due to the incorporation of $\mathrm{M}$ ions belonging to the clays with the formation of the $\mathrm{P}-\mathrm{O}-\mathrm{M}$ bonds (with $\mathrm{M}=\mathrm{Si}, \mathrm{Fe}, \mathrm{Al}$, and $\mathrm{Mg}$ ), which become covalent with a higher rate of clay oxides, which allows the reinforcement of the glassy networks $18,20,27,28$. This result is well correlated with the evolution of density and molar volume measurements that suggest the compactness of the glass structure ${ }^{27}$.

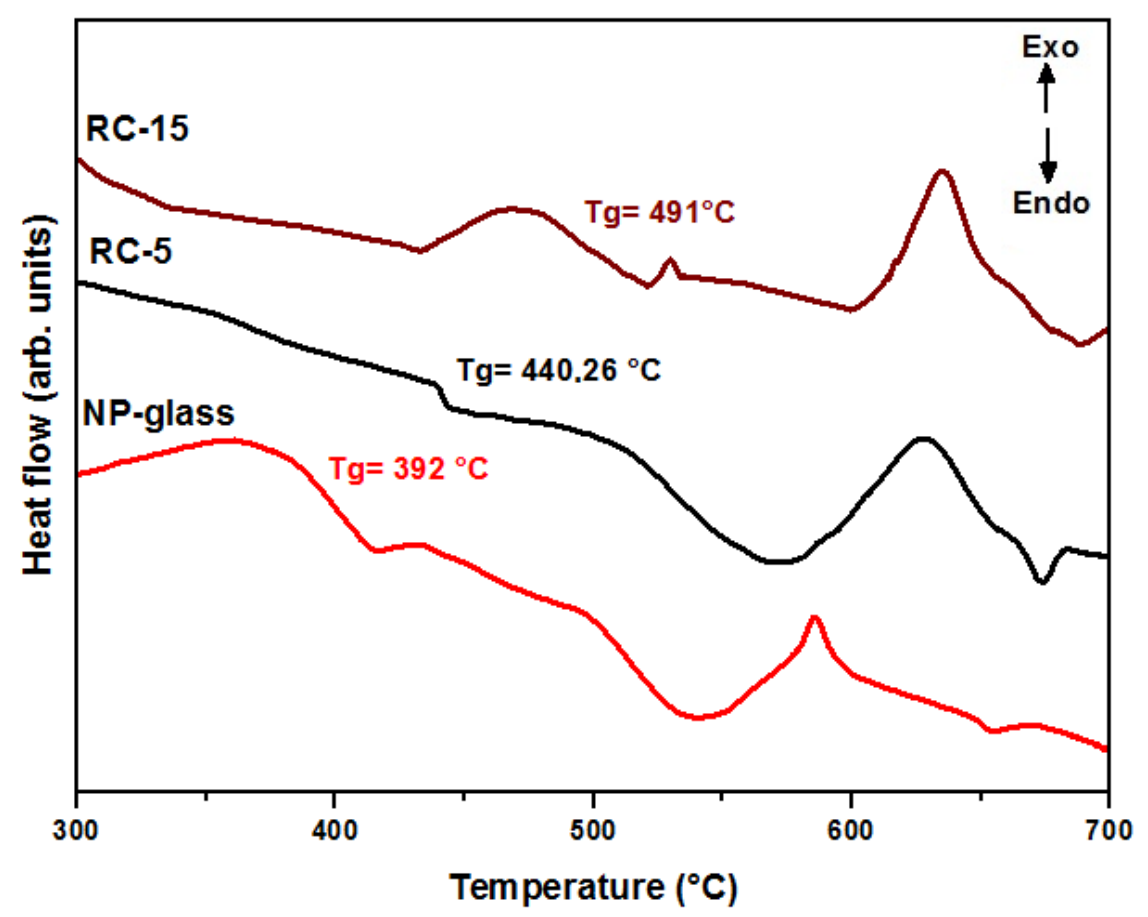

Figure 6. DSC curves for NP-glass, RC-5, and RC-15 phosphate glasses. 
Table 6. Values of density $\left(\rho_{\mathrm{g}}\right)$, molar volume $(\mathrm{Vm})$, and transition temperature $(\mathrm{Tg})$ of the PGs.

\begin{tabular}{|c|c|c|c|}
\hline Glass code & $\rho g\left(g_{\cdot} \mathrm{cm}^{-3}\right)$ & $\mathrm{Vm}\left(\mathrm{cm}^{3} \cdot \mathrm{mol}^{-1}\right)$ & $\operatorname{Tg}\left({ }^{\circ} \mathbf{C}\right)$ \\
\hline NP-glass & 2.6359 & 44.54 & 392 \\
\hline RC-2 & 2.8019 & 42.30 & 426 \\
\hline RC-5 & 2.8517 & 41.45 & 440 \\
\hline RC-10 & 2.9302 & 39.11 & 487 \\
\hline RC-15 & 2.9542 & 38.73 & 491 \\
\hline
\end{tabular}

\subsubsection{Infrared and Raman spectroscopies}

The structural modifications of the elaborated glasses according to the oxide content in the clay were studied by infrared and Raman spectroscopies. The FTIR and Raman spectra of the investigated PGs
(NP-glass, RC-2, RC-2, RC- 5, RC-10, and RC-15) are shown in Fig. 7a and Fig. 7b, respectively. The assignments of the infrared and Raman bands are listed in Table 7.

Table 7. Infrared and Raman assignments $\left(\mathrm{cm}^{-1}\right)$ of the elaborated PGs.

\begin{tabular}{|c|c|c|c|c|c|c|c|c|c|c|c|c|}
\hline \multirow{2}{*}{$\begin{array}{l}\text { Glass } \\
\text { code }\end{array}$} & \multicolumn{2}{|c|}{$v_{\text {as }}\left(\mathbf{P O}_{2}\right)$} & \multicolumn{2}{|c|}{$v_{\mathrm{s}}\left(\mathbf{P O}_{2}\right)$} & \multicolumn{2}{|c|}{$\begin{array}{c}\mathrm{v}_{\text {as }}\left(\mathrm{PO}_{3}\right) \text { and } \\
\mathbf{v}_{\mathbf{s}}\left(\mathrm{PO}_{3}\right)\end{array}$} & \multicolumn{2}{|c|}{$v_{\text {as }}(\mathbf{P O P})$} & \multicolumn{2}{|c|}{$\mathbf{v}_{\mathrm{s}}(\mathbf{P O P})$} & \multicolumn{2}{|c|}{$\delta\left(\mathrm{PO}_{4}{ }^{3-}\right)$} \\
\hline & IR & Raman & IR & Raman & IR & Raman & IR & Raman & IR & Raman & IR & Raman \\
\hline NP-glass & 1298 & 1298 & 1173 & 1181 & 1095 & - & 910 & 940 & 760 & 698 & 526 & - \\
\hline RC-2 & 1298 & 1285 & 1173 & 1175 & 1093 & - & 910 & 940 & 760 & 692 & 527 & 501 \\
\hline RC-5 & 1296 & 1284 & - & 1175 & 1091 & - & 910 & - & 758 & 692 & 527 & 508 \\
\hline RC-10 & 1289 & 1280 & 1169 & 1173 & 1089 & - & 914 & - & 756 & 690 & 533 & 513 \\
\hline RC-15 & 1286 & 1280 & - & 1171 & 1087 & - & 914 & - & 754 & 690 & 540 & - \\
\hline
\end{tabular}

As shown in Fig. 7a, six bands of the IR spectra of the reference glass were observed at 1298, 1173, $1095,910,760$, and $526 \mathrm{~cm}^{-1}$. There is no significant change in infrared spectra for glasses containing 2 and $5 \%$ by weight of clay. These results may be due to the conservation of the structure, which is essentially based on ultraphosphate groups $\left(\mathrm{Q}^{3}\right)^{26}$. The bands observed around 1298 and $1173 \mathrm{~cm}^{-1}$ are attributed to the asymmetric stretching vibration mode $v_{\mathrm{as}}\left(\mathrm{PO}_{2}\right)$ and symmetric $\mathrm{v}_{\mathrm{s}}\left(\mathrm{PO}_{2}\right)$ where the two oxygen atoms without bridging (O-P-O) easily connect to a phosphorus atom in the phosphate tetrahedron in the intermediate structural units $\left(\mathrm{Q}^{2}\right)$ $8,24,25$. The band at $1095 \mathrm{~cm}^{-1}$ is attributed to the asymmetric stretching of the groups $v_{\text {as }}\left(\mathrm{PO}_{3}\right)$ characteristic of the structural units $\left(Q^{1}\right)^{24,25}$. With the addition of clay from $10 \%$ to $15 \%$ by weight, we notice the widening of these bands and a shift to lower wavenumbers with a reduction in intensity; this decrease in intensity reflects an increase in the contents of modifier oxides and suggests a reduction in the number of non-bridging $\mathrm{P}-\mathrm{O}$ bonds with a progressive increase in connectivity ${ }^{2,25,29}$.

Furthermore, the overlap of these bands can also be attributed to the $\mathrm{Si}-\mathrm{O}(\mathrm{Si})$, and $\mathrm{Si}-\mathrm{O}(\mathrm{P})$ links ${ }^{2,25}$. Also, the bands observed around 910 and $760 \mathrm{~cm}^{-1}$ in the IR spectra of the phosphate glasses were attributed to the symmetric and asymmetric stretching of the P-O-P bridge bonds, respectively. These two bands are obtained in species $\left(Q^{2}\right)^{24,25}$. However, this time, the bands increased to higher wavenumbers around $916 \mathrm{~cm}^{-1}$ and decreased to lower wavenumbers of around $756 \mathrm{~cm}^{-1}$ with decreasing intensity for RC-10 and RC-15 glasses. These changes can be explained by the increase in the covalency of the P-O-P bonds which are replaced by that of $\mathrm{P}-\mathrm{O}-\mathrm{M}$ with the formation of chain termination units $\left(\mathrm{Q}^{1}\right)$ as the $\mathrm{O} / \mathrm{P}$ ratio increases $2,9,20,25,29$. At last, the bands around $526 \mathrm{~cm}^{-1}$ are assigned to the deformation bands of the groups $\mathrm{P}_{-} \mathrm{O}^{-}$ $\left(\mathrm{PO}_{4}^{3-}\right)$, vibration band of $(\mathrm{O}-\mathrm{P}-\mathrm{O})$ in phosphate dimers $\left(Q^{1}\right)^{24,25}$.

The Raman spectrum of the reference glass (NPglass) (Fig. 7b) reveals two full bands at 1298 and $1181 \mathrm{~cm}^{-1}$ that are attributed to the asymmetric and symmetric vibrations of P-O-P $\left(\mathrm{v}_{\text {as }}\left(\mathrm{PO}_{2}\right)\right.$ and $\left.v_{\mathrm{s}}\left(\mathrm{PO}_{2}\right)\right)$ in the chains $\left(\mathrm{Q}^{2}\right)^{8,30}$. The band at $698 \mathrm{~cm}^{-1}$ is attributed to the symmetric vibration $v_{\mathrm{s}}(\mathrm{POP})$ of bridging oxygen connecting two tetrahedra $\mathrm{PO}_{4}(\mathrm{P}-$ $\mathrm{O}-\mathrm{P})$ in phosphate chains $\left(\mathrm{Q}^{2}\right)^{8,30}$. The band observed around $501 \mathrm{~cm}^{-1}$ is related to the deformation vibration of (O-P-O) in the structural chains $\left(Q^{1}\right)^{30}$. With the increase in clay content, we observe a decrease in the general bottom in the ranges of $1100-1300 \mathrm{~cm}^{-1}$ and $600-800 \mathrm{~cm}^{-1}$. These changes can be attributed to the breakage of P-O-P 
bonds and the depolymerization of phosphate chains with the formation of the P-O-M bonds. Accordingly, as the $\mathrm{O} / \mathrm{P}$ ratio increases, structural units $\left(Q^{1}\right)$ are also formed ${ }^{27,30}$. We notice the appearance of a new band that probably comes from the vibrations of the $\mathrm{Si}-\mathrm{O}-\mathrm{Si}$ bridge in the siliconoxygen units $\left(\mathrm{Q}^{2}\right)$ (about $\left.620 \mathrm{~cm}^{-1}\right)^{2}$.
Summing up the results of the FTIR and Raman spectroscopies and the values of the O/P ratio, it can be concluded that the structure of these glasses contains a mixture of ultraphosphate and polyphosphate structural units whose concentrations depend on the composition of the glasses.
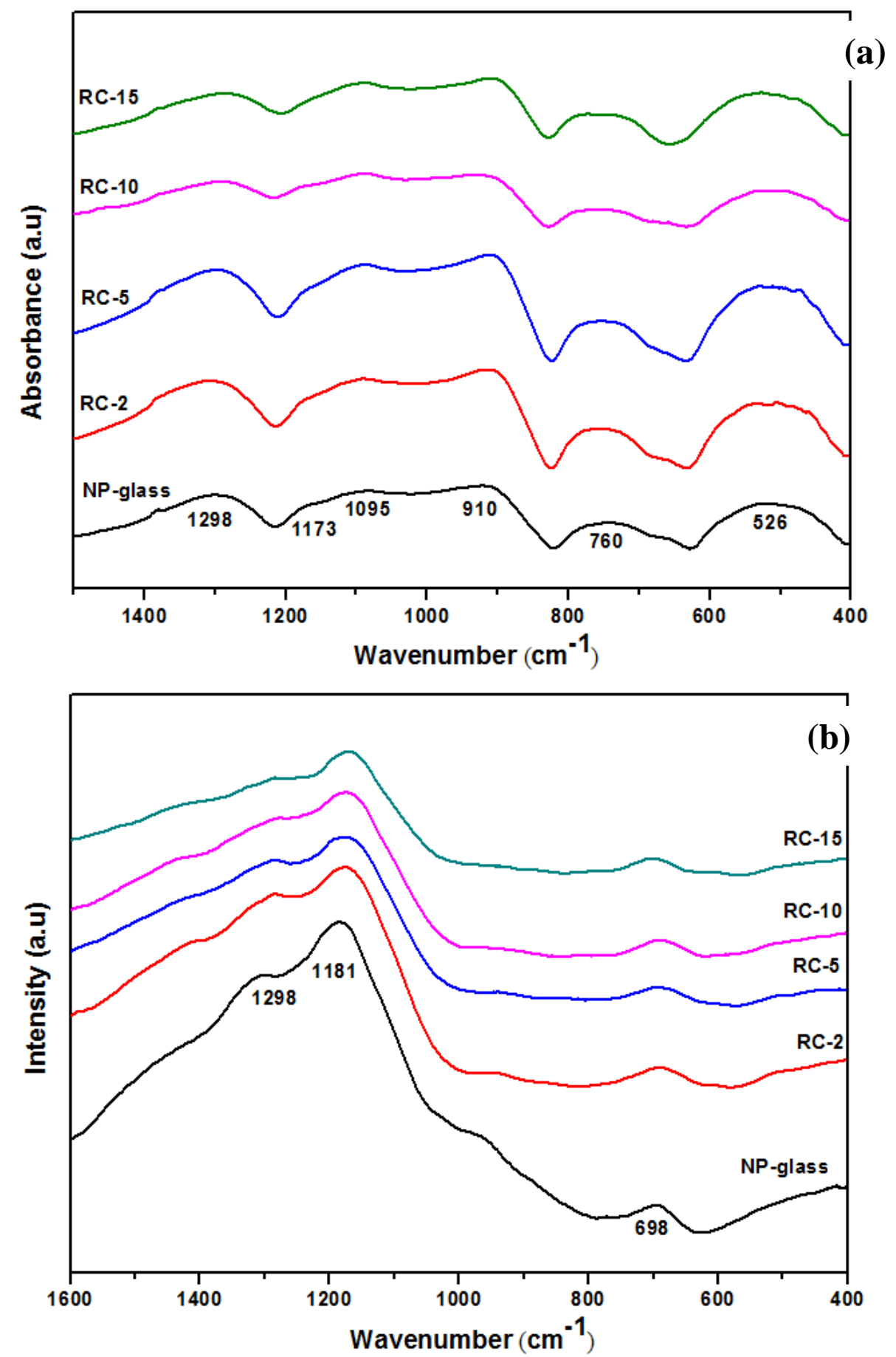

Figure 7. (a) FTIR spectra and (b) Raman spectra of the elaborated PGs with increasing RC content.

\subsubsection{Chemical durability}

In order to show the effect of oxides belonging to red clay on the chemical durability of glasses, the dissolution rate $\left(D_{R}\right)$ as a function of the clay percentage at different $\mathrm{pH}$ values of the immersion solution is presented in Fig. 8. Clearly, for all glasses, it is known that the dissolution rate is higher under basic conditions. However, for all $\mathrm{pH}$ values, the minimum $D_{R}$ rate is observed for RC-15 glass which has the minimum molar percentage of $\mathrm{P}_{2} \mathrm{O}_{5}$. It should also be noted that, although density and $\mathrm{Tg}$ increase proportionally with the addition of clay, 
chemical durability is also considerably improved. RC-15 glass also has a maximum value of these quantities. We can conclude that the chemical durability increases with increasing clay percentage up to $15 \%$ and that $\mathrm{RC}-15$ glass is the most resistant of these glasses.

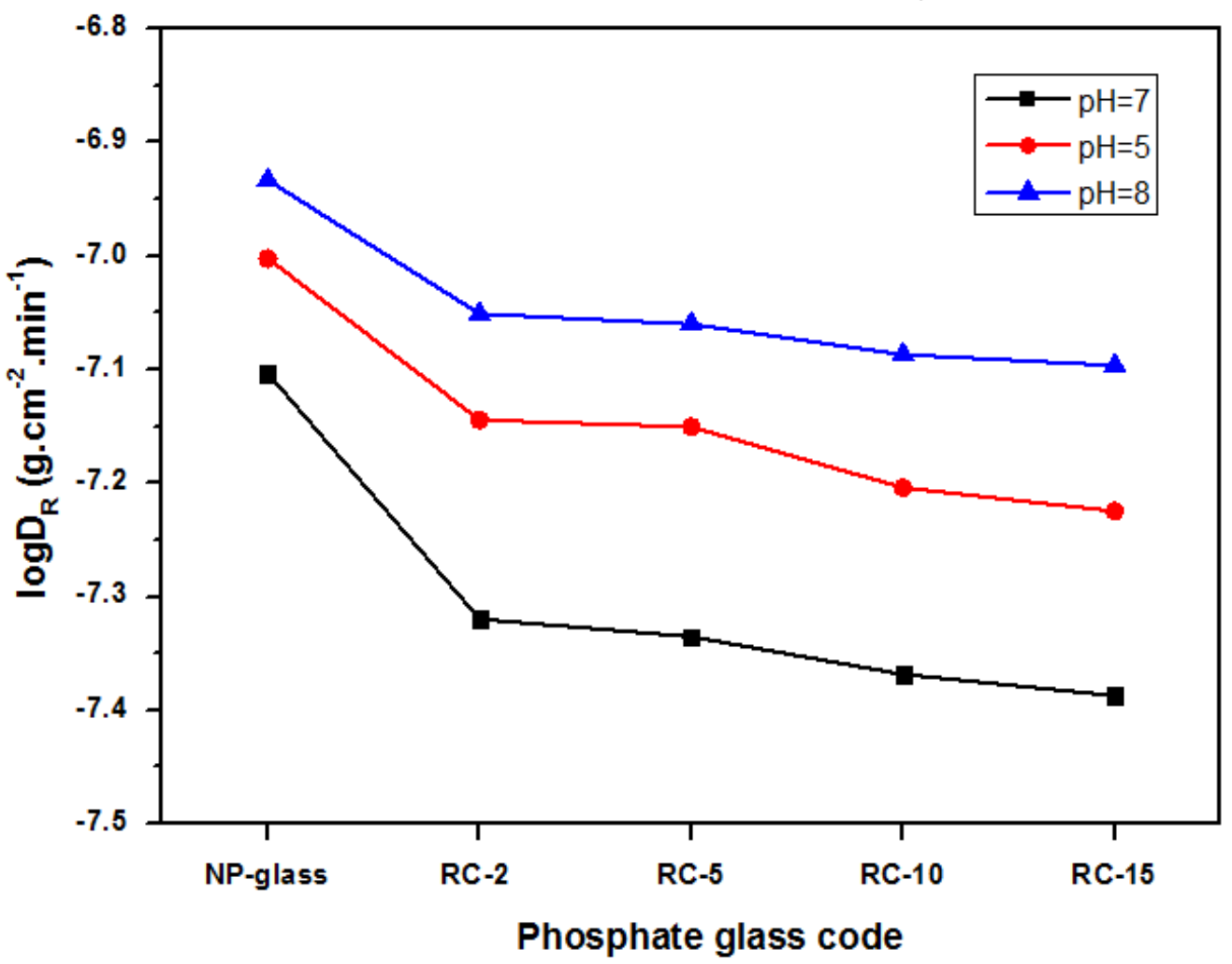

Figure 8. Variation of the dissolution rate $D_{R}$ as a function of the weight percentage of red clay in PGs.

We can also affirm that the increase in the percentage of oxides such as $\mathrm{SiO}_{2}, \mathrm{Fe}_{2} \mathrm{O}_{3}, \mathrm{Al}_{2} \mathrm{O}_{3}$, and $\mathrm{MgO}$ with the decrease in the percentage of oxides $\mathrm{P}_{2} \mathrm{O}_{5}$ and $\mathrm{CaO}$ in the structure of glass leads to the formation of P-O-Si, P-O-Fe, P-O-Al, and O-P-Mg bonds. Hence, this allows an increase in the bond strength, including the rigidity of the glass network, and leads to improved chemical durability of the glass.

Therefore, as compared to previous studies ${ }^{31-37}$, it was confirmed that the dissolution of these phosphate glasses decreases with the increase of the added oxides belonging to the red clay.

\section{Conclusions}

In this paper, new phosphates glasses formulations based on Moroccan natural phosphate alone or with Moroccan red clay from the $\mathrm{P}_{2} \mathrm{O}_{5}-\mathrm{SiO}_{2}-\mathrm{CaO}-\mathrm{Al}_{2} \mathrm{O}_{3}-$ $\mathrm{MgO}-\mathrm{Fe}_{2} \mathrm{O}_{3}-\mathrm{K}_{2} \mathrm{O}-\mathrm{Na}_{2} \mathrm{O}-\mathrm{TiO}_{2}$ complex system have been successfully prepared by the quenching method. Synthesized phosphate glasses containing mainly macroelements and microelements will be used to develop phosphate glass fibers acting as a slow-release fertilizer.

All elaborated phosphate glasses are homogeneous with a smooth surface, as shown by SEM analysis. The vitreous state of the elaborated glasses was confirmed by XRD and DSC. The structural changes investigated with FTIR and Raman spectroscopies suggested depolymerization and a stronger crosslinking of phosphate chains with the addition of the red clay increasing density and glass transition temperature. Conversely, the molar volume decreases monotonously with the introduction of clay. These changes were explained by the formation of the more covalent $\mathrm{P}-\mathrm{O}-\mathrm{M}$ bonds (with $\mathrm{M}=\mathrm{Si}, \mathrm{Fe}$, $\mathrm{Al}$, and $\mathrm{Mg}$ ) replacing the $\mathrm{P}-\mathrm{O}-\mathrm{P}$ bonds, which also increases the rigidity of the glass network allowing the compactness of the structure.

The chemical durability of investigated phosphate glasses was evaluated in terms of dissolution rate $\left(D_{R}\right)$, and the results show that the dissolution rate decreased with increasing of the red clay up to $15 \%$ by weight percentage for RC- 15 glass belonging to the $\quad 41 \mathrm{P}_{2} \mathrm{O}_{5}-23.5 \mathrm{SiO}_{2}-25 \mathrm{CaO}-3.9 \mathrm{Al}_{2} \mathrm{O}_{3}-3.6 \mathrm{MgO}-$ $2.9 \mathrm{Fe}_{2} \mathrm{O}_{3}-3.2 \mathrm{~K}_{2} \mathrm{O}-0.6 \mathrm{Na}_{2} \mathrm{O}-0.27 \mathrm{TiO}_{2}$ system. Based on the results, the chemical durability was improved with an increase in oxides belonging to the red clay.

\section{References}

1- M. Schumacher, L. Reither, J. Thomas, M. Kampschulte, U. Gbureck, A. Lode, and M. Gelinsky, Calcium phosphate bone cement/mesoporous bioactive glass composites for controlled growth factor delivery, Biomaterials Science, 2017, 5(3), 578-588. 
2- I. Waclawska, M. Szumera, and S. Justyna, Structural characterization of zinc-modified glasses from the $\mathrm{SiO}_{2}-\mathrm{P}_{2} \mathrm{O}_{5}-\mathrm{K}_{2} \mathrm{O}-\mathrm{CaO}-\mathrm{MgO}$ system, J. of Alloys and Compounds, 2016, 666, 352-358.

3- N. Kitamura, A. Nomura, A. Saitoh, H. Kobayashi, I. Amamoto, and H. Takebe, Effect of $\mathrm{ZrO}_{2}$ addition on water durability of $\mathrm{FeO}-\mathrm{Fe}_{2} \mathrm{O}_{3}-\mathrm{P}_{2} \mathrm{O}_{5}$ glasses, J. of the Ceramic Society of Japan, 2018, 126(11), 948-951.

4- L. Badr, Low-temperature conductivity and ion dynamics in silver iodide-silver metaphosphate glasses, Physical Chemistry Chemical Physics, 2017, 19(32), 21527-21531.

5- H. Bih, L. Bih, B. Manoun, M. Azrour, B. Elouadi, and P. Lazor, Electrical Transport Properties of Iodine Oxide Phosphate Glasses Issued from The $\mathrm{NaI}-\mathrm{Li}_{2} \mathrm{O}-\mathrm{WO}_{3}-\mathrm{P}_{2} \mathrm{O}_{5}$ System, Moroccan Journal of Condensed Matter, 2010, 12(2).

6- C. Chen, R. He, Y. Tan, B. Wang, S. Akhmadaliev, S. Zhou, S, and F. Chen, Optical ridge waveguides in $\mathrm{Er}^{3+} / \mathrm{Yb}^{3+}$ co-doped phosphate glass produced by ion irradiation combined with femtosecond laser ablation for guided-wave green and red upconversion emissions, Optical Materials, 2016, 51, 185-189.

7- M. Haouari, and N. Saad, On the Origin of the Large Stokes-Shift of the Emission of CdS Nanoparticles Embedded in a Phosphate Glass Matrix, J. of Cluster Science, 2018, 29(2), 391-402.

8- A. Chahine, M. Et-Tabirou, M. Elbenaissi, M. Haddad, and J.L. Pascal, Effect of $\mathrm{CuO}$ on the structure and properties of $(50-\mathrm{x} / 2)$

$\mathrm{Na}_{2} \mathrm{O}-\mathrm{xCuO}-(50-\mathrm{x} / 2) \mathrm{P}_{2} \mathrm{O}_{5}$ glasses. Materials chemistry and physics, 2004, 84(2-3), 341-347.

9- N. Sharmin, N., and C.D. Rudd, Structure, thermal properties, dissolution behaviour and biomedical applications of phosphate glasses and fibres: a review, Journal of Materials Science, 2017, 52(15), 8733-8760.

10-G. K. Marasinghe, C.S. Ray, M. Karabulut, D. E Day, M. G. Shumsky, W.B. Yelon, and D.K. Shuh, Structural features of iron phosphate glasses, J. Non-Cryst Solids 1997, 222, 144-52.

11- I. Ahmed, M. Lewis, I. Olsen, and J. C. Knowles, Phosphate glasses for tissue engineering: Part 1. Processing and characterisation of a ternary-based $\mathrm{P}_{2} \mathrm{O}_{5}-\mathrm{CaO}-$ $\mathrm{Na}_{2} \mathrm{O}$ glass system, Biomaterials, 2004, 25(3), 491-499.

12-H. Yung, P. Y. Shih, H. S. Liu, and T. S. Chin, Nitridation Effect on Properties of Stannous-Lead Phosphate Glasses, J. of the American Ceramic Society, 1997, 80(9), 2213-2220.

13-R. A. Khan, A. J. Parsons, I. A. Jones, G. S. Walker, and C. D. Rudd, Degradation and interfacial properties of iron phosphate glassfibre-reinforced PCL-based composite for synthetic bone replacement materials, Polymer-
Plastics Technology and Engineering, 2010, 49(12), 1265-1274.

14-D. S. Brauer, C. Rüssel, and J. Kraft, Solubility of glasses in the system $\mathrm{P}_{2} \mathrm{O}_{5}-\mathrm{CaO}-\mathrm{MgO}-\mathrm{Na}_{2} \mathrm{O}-$ $\mathrm{TiO}_{2}$ : Experimental and modeling using artificial neural networks, J. of non-crystalline solids, 2007, 353(3), 263-270.

15-C. S. Ray, X. Fang, M. Karabulut, G.K. Marasinghe, D.E. Day, Effect of melting temperature and time on iron valence and crystallization of iron phosphate glasses, J. NonCryst Solids 1999, 249, 1-16.

16-M. Jerroudi, L. Bih, M. Azrour, B. Manoun, I. Saadoune, and P. Lazor, Investigation of Novel Low Melting Phosphate Glasses Inside the $\mathrm{Na}_{2} \mathrm{O}-\mathrm{K}_{2} \mathrm{O}-\mathrm{ZnO}-\mathrm{P}_{2} \mathrm{O}_{5}$ System, J. of Inorganic and Organometallic Polymers and Materials, 2019, 1-11.

17-G. Walter, J. Vogel, U. Hoppe, and P. Hartmann, The structure of $\mathrm{CaO}-\mathrm{Na}_{2} \mathrm{O}-\mathrm{MgO}-\mathrm{P}_{2} \mathrm{O}_{5}$ invert glass, J. of non-crystalline solids, 2001, 296(3), 212-223.

18-F. Behrends, and H. Eckert, Mixed-Alkali Effects in Aluminophosphate Glasses: A Re-examination of the System $\left[\mathrm{x} \mathrm{Na}_{2} \mathrm{O}(1-\mathrm{x}) \mathrm{Li}_{2} \mathrm{O}\right] 0.46\left[\mathrm{y} \mathrm{Al}_{2} \mathrm{O}_{3}\right.$ (1-y) $\mathrm{P}_{2} \mathrm{O}_{5}$ ] 0.54, The Journal of Physical Chemistry C, 2011, 115(34), 17175-17183.

19-British Standards Institution, BS 10119, 2002, London.

20-L. Abbas, L. Bih, A. Nadiri, Y. El Amraoui, H. Khemakhem, and D. Mezzane, Chemical durability of $\mathrm{MoO}_{3}-\mathrm{P}_{2} \mathrm{O}_{5}$ and $\mathrm{K}_{2} \mathrm{O}-\mathrm{MoO}_{3}-\mathrm{P}_{2} \mathrm{O}_{5}$ glasses, J. of Thermal Analysis and Calorimetry, 2007, 90(2), 453-458.

21-M. Monsif, S. Rossignol, F. Allali, A. Zerouale, N. I. Kandri, E. Joussein, and R. Bertani, The implementation of geopolymers materials from Moroccan clay, within the framework of the valorization of the local natural resources, $\mathrm{J}$. Mater. Environ. Sci, 2017, 8, 2704-2721.

22-A. Qlihaa, S. Dhimni, F. Melrhaka, N. Hajjaji, and A. Srhiri, Physico-chemical characterization of a Morrocan clay, J. Mater. Environ. Sci, 2016, 7(5), 1741-1750.

23-L. Ma, r. k. Brow, and M. E. Schlesinger, Dissolution behaviour of sodium-calcium polyphosphate glasses, Physics and Chemistry of Glasses-European Journal of Glass Science and Technology Part B, 2018, 59(5), 205-212.

24-M. A. Cherbib, I. Khattech, L. Montagne, B. Revel, and M. Jemal, Structure properties relationship in calcium sodium metaphosphate and polyphosphate glasses, J. of Non-Crystalline Solids, 2018, 485, 1-13.

25-W. Jastrzębski, M. Sitarz, M. Rokita, and K. Bułat, Infrared spectroscopy of different phosphates structures. Spectrochimica Acta Part A: Molecular and Biomolecular Spectroscopy, 2011, 79(4), 722-727.

26-C. Tan, I. Ahmed, A. J. Parsons, N. Sharmin, C. Zhu, J. Liu, and X. Liu, Structural, thermal and dissolution properties of $\mathrm{MgO}$-and $\mathrm{CaO}$ - 
containing borophosphate glasses: effect of $\mathrm{Fe}_{2} \mathrm{O}_{3}$ addition, J. of materials science, 2017, 52(12), 7489-7502.

27-R. O. Omrani, S. Krimi, J. J. Videau, I. Khattech, A. El Jazouli, and M. Jemal, Structural and thermochemical study of $\mathrm{Na}_{2} \mathrm{O}-\mathrm{ZnO}-\mathrm{P}_{2} \mathrm{O}_{5}$ glasses, J. of Non-Crystalline Solids, 2014, 390, 5-12.

28-N. H. Ray, Composition-property relationships in inorganic oxide glasses, J. of Non-Crystalline Solids, 1974, 15(3), 423-434.

29-P. Rajbhandari, L. Montagne, and G. Tricot, Doping of low-Tg phosphate glass with $\mathrm{Al}_{2} \mathrm{O}_{3}$, $\mathrm{B}_{2} \mathrm{O}_{3}$ and $\mathrm{SiO}_{2}$ : Part II-insertion mechanism of $\mathrm{Al}_{2} \mathrm{O}_{3}$ and $\mathrm{B}_{2} \mathrm{O}_{3}$ in phosphate network characterized by $1 \mathrm{D} / 2 \mathrm{D}$ solid-state NMR, Materials Chemistry and Physics, 2018, 218, 122-129.

30-A. M. B. Silva, R. N. Correia, J. M. M. Oliveira, and M. H. V. Fernandes, Structural characterization of $\mathrm{TiO}_{2}-\mathrm{P}_{2} \mathrm{O}_{5}-\mathrm{CaO}$ glasses by spectroscopy, J. of the European Ceramic Society, 2010, 30(6), 1253-1258.

31-M. S. Hasan, I. Ahmed, A. J. Parsons, G. S. Walker, and C. A. Scotchford, Material characterisation and cytocompatibility assessment of quinternary phosphate glasses, J. of Materials Science: Materials in Medicine, 2012, 23(10), 2531-2541.

32-M. K. Hwang, and B. K. Ryu, Study on the water durability of zinc boro-phosphate glasses doped with $\mathrm{MgO}, \mathrm{Fe}_{2} \mathrm{O}_{3}$, and $\mathrm{TiO}_{2}$, J. of the Korean Physical Society, 2016, 69(2), 157-163.
33-A. Le Sauze, and R. Marchand, chemically durable nitrided phosphate glasses resulting from nitrogen/oxygen substitution within $\mathrm{PO}_{4}$ tetrahedra, J. of Non-Crystalline Solids, 2000, 263, 285-292.

34-I. Waclawska, and M. Szumera, Reactivity of silicate-phosphate glasses in the soil environment, J. of Alloys and Compounds, 2009, 468(1-2), 246-253.

35-H. K. Lee, S. J. Hwang, and W. H. Kang, Preparation of $\mathrm{K}_{2} \mathrm{O}-\mathrm{CaO}-\mathrm{P}_{2} \mathrm{O}_{5}$ eco-glass fertilizers and effect in crops, In Materials Science Forum, Trans Tech Publications, 2005, 486, 407-410.

36-H. Gao, T. Tan, and D. Wang, Dissolution mechanism and release kinetics of phosphate controlled release glasses in aqueous medium, $\mathrm{J}$. of controlled release, 2004, 96(1), 29-36.

37-K. Franks, V. Salih, J. C. Knowles, and I. Olsen, The effect of $\mathrm{MgO}$ on the solubility behavior and cell proliferation in a quaternary soluble phosphate based glass system, J. of Materials Science: Materials in Medicine, 2002, 13(6), 549-556.

38-J. O. Byun, B. H. Kim, K. S. Hong, H. J. Jung, S. W. Lee, and A. A. Izyneev, Properties and structure of $\mathrm{RO}-\mathrm{Na}_{2} \mathrm{O}-\mathrm{Al}_{2} \mathrm{O}_{3}-\mathrm{P}_{2} \mathrm{O}_{5}(\mathrm{R}=\mathrm{Mg}, \mathrm{Ca}$, $\mathrm{Sr}, \mathrm{Ba})$ glasses, J. of non-crystalline solids, 1995, 190(3), 288-295.

39-U. B. Chanshetti, V. A. Shelke, S. M. Jadhav, S. G. Shankarwar, T. K. Chondhekar, A. G. Shankarwar, and M. S. Jogad, Density and molar volume studies of phosphate glasses, Facta universitatis-series: Physics, Chemistry and Technology, 2011, 9(1), 29-36. 